\title{
52. CENOZOIC EVOLUTION OF CARBONATE PLATFORMS ON THE NORTHEASTERN AUSTRALIAN MARGIN: SYNTHESIS OF LEG 133 DRILLING RESULTS ${ }^{1}$
}

\author{
Judith A. McKenzie ${ }^{2}$ and Peter J. Davies ${ }^{3}$
}

\begin{abstract}
Drilling during Ocean Drilling Program (ODP) Leg 133 was designed to study factors controlling both isolated and attached carbonate-platform evolution using sedimentary sequences that were deposited at varying water depths on the platform margins and slopes and in the adjoining basins. Shipboard and post-cruise data provide an integrated picture of the conditions promoting platform initiation and growth, as well as the environmental changes that can lead to platform demise. Results indicate that the Cenozoic evolution of the Queensland Plateau, Marion Plateau, and Great Barrier Reef was controlled by a complex interaction of variations in eustatic sea level, subsidence pulses, and paleoceanographic changes. In most cases, not a single factor, but a combination of factors was in operation at any specific time. Long-term platform development was strongly influenced by the northward drift of the Australian Plate throughout the Cenozoic. Plate motion resulted in a transition from temperate to tropical surface-water temperatures, with a corresponding change in the type of carbonate sedimentation. Yet, short-term, rapid changes in paleoceanography seem to have dominated the system. Abrupt increases in surface-water temperatures led to the sudden development of extensive tropical reefal complexes in the early Miocene, whereas a decrease in late Miocene surface-water temperatures resulted in a change from tropical fauna and flora to a bio-assemblage more compatible with a nontropical environment. Together with the paleoceanographic changes, variations in relative sea level, whether eustatically or tectonically controlled, either helped maintain carbonate production or facilitated its decrease, sometimes resulting ultimately in the shutdown of the shallow-water carbonate factories. During specific time periods, the thermally driven circulation of seawater through the buried carbonate platform sediments apparently caused selective dolomitization. This process may be ongoing within the Queensland Plateau, possibly providing new clues for understanding massive carbonate platform dolomitization.
\end{abstract}

\section{INTRODUCTION}

Ancient carbonate platforms exposed on land are remarkable edifices, often forming fortresslike mountains that rise out of the surrounding basinal sediments. The Permian El Capitan reef of west Texas, the Triassic platforms of the Dolomites in northern Italy, and the Devonian reef complexes of the Canadian Rockies are some of the magnificent examples of carbonate platforms that have undergone intensive scientific investigation. As these platforms often serve as oil and gas reservoirs, a driving force behind this research has been the acknowledged need to understand their evolution from initiation through later-stage diagenesis to evaluate their reservoir potential better. Increased porosity is crucial for a good reservoir, and diagenetic processes, such as dolomitization, tend to improve reservoir quality. Hence, carbonate petrologists have concentrated much research effort toward understanding diagenetic processes in ancient carbonate platforms.

Recently, the dynamic carbonate factories producing the sediments and the associated facies relationships have been the focus of studies about modern carbonate platforms, such as the Bahamian Platform. These modern platform studies have been useful in providing actualistic models to evaluate the factors that have influenced the development and diagenesis of their ancient counterparts, as well as to provide an exploration tool. But, despite the intensive research effort in both ancient and modern systems, major controversies remain concerning the processes controlling the initiation and long-term evolution of carbonate platforms (Eberli, 1991). Factors terminating platform growth are even more debatable, as carbonate platforms are dynamic systems that, once initiated, have potential growth rates fast enough to keep up with changes induced by most geological processes. A healthy

\footnotetext{
${ }^{1}$ McKenzie, J.A., Davies, P.J., Palmer-Julson, A., et al., 1993, Proc. ODP, Sci. Results, 133: College Station, TX (Ocean Drilling Program).

${ }^{2}$ Geologisches Institut, Eidgenossische Technische Hochschule, Sonneggstrasse 5 , CH-8092 Zürich, Switzerland.

${ }^{3}$ Department of Geology and Geophysics, The University of Sydney, Sydney, N.S.W. 2006, Australia.
}

platform with a high growth potential should be able to compete constructively against destructive forces. What causes then can lead to the slowdown or termination of these dynamic processes?

Drilling during Leg 133 on the northeastern Australian margin provided a unique opportunity to evaluate the various factors influencing carbonate platform development in an active system that has been basically a marine environment throughout its entire Cenozoic history (Davies, McKenzie, Palmer-Julson, et al., 1991). Major drilling objectives addressed controversial problems concerning platform initiation, growth, and demise by studying the temporal and spatial evolution of the Queensland Plateau, Marion Plateau, and Great Barrier Reef (Fig. 1). The Queensland Plateau is an isolated, partially drowned carbonate platform far from land and the influence of detrital flux from the Australian continent and can be considered a pure carbonate system. In contrast, the Marion Plateau and Great Barrier Reef are attached carbonate platforms on the continental margin and have a greater potential for receiving siliciclastic material. The latter two represent mixed siliciclastic-carbonate systems. Similar to the Queensland Plateau, the Marion Plateau is a partially drowned platform, while the Great Barrier Reef is the location of modern platform growth on the northeastern Australian margin. Taken together, the platforms on the northeastern Australian margin provide an ideal setting to study the influence of various factors on the evolution of these carbonate platforms, including fluctuations in sea level caused by glacial eustatic control and tectonic factors, variations in paleoclimate resulting from plate motion, and changing paleoceanography, as well as variable diagenetic histories. The goal of this research was to delineate the controls on platform development in a stratigraphic context using drill holes situated along two transects crossing varying geographical settings and water depths.

The more northerly east-west transect across the Queensland Trough (Fig. 2) comprises four sites (Sites 819-822) in water depths ranging from 211 to $955 \mathrm{~m}$ on the slopes of the Australian continental shelf directly in front of the Great Barrier Reef, a basinal site (Site 823 ) in a water depth of $1638 \mathrm{~m}$ near the center of the Trough, and two locations (Sites $811 / 825$ and 824 ) on the western slopes of the 


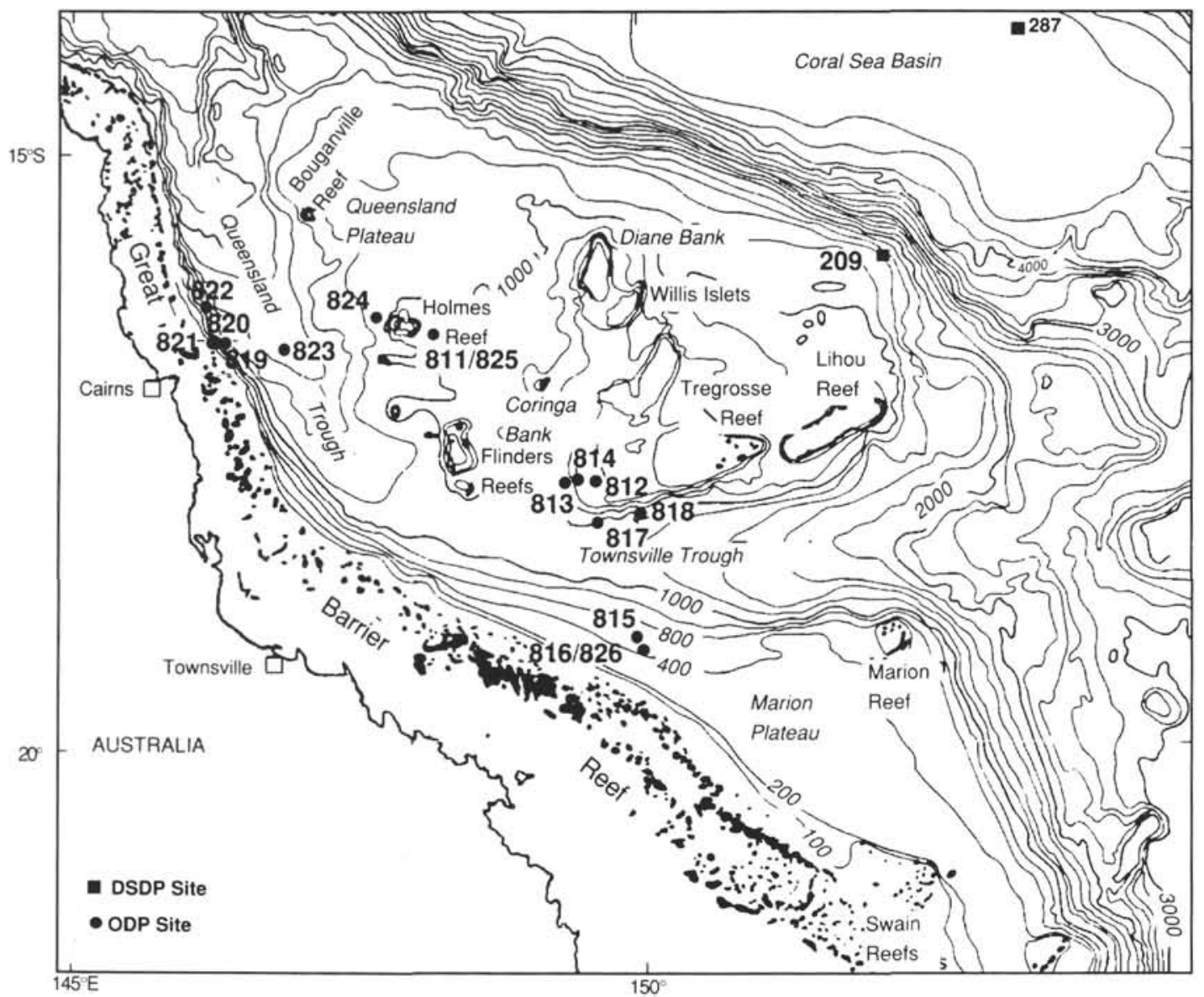

Figure 1. Bathymetric map of northeastern Australian margin showing Leg 133 site locations. Bathymetry in meters.

Queensland Plateau at water depths of about $1000 \mathrm{~m}$ in the vicinity of Holmes Reef (Fig. 1). At the sites in front of the Great Barrier Reef, drilling recovered Pliocene-Pleistocene sequences of mixed carbonate/siliciclastic sediments, the major results of which are summarized in detail in the preceding synthesis chapter (Davies and McKenzie, this volume). At the basinal site, an extended sequence of turbidite, debris flow and slump deposits recorded the history of changes in composition and nature of gravity deposits since the late middle Miocene as a function of tectonic movements, fluctuations in eustatic sea level, and sedimentological factors. At the sites on the western slopes of the Queensland Plateau, which penetrated crystalline basement, a record of carbonate sedimentation since the middle Eocene was obtained that provided information about the influence of environmental changes on evolving sedimentation patterns throughout the Cenozoic history of the platform.

The north-south trending transect across the Townsville Trough (Fig. 3) contains sites positioned on the margins and slopes of the Queensland and Marion plateaus to study extensive carbonate buildups previously identified in seismic profiles (Davies et al., 1989). Sites 812 through 814 in water depths of 460 to $540 \mathrm{~m}$ represent a subtransect on the southern margin of the Queensland Plateau from a lagoonal bank complex to an aggradational/progradational sequence in front of the carbonate build-up. Continuing downslope, Sites 818 and 817 , respectively, in water depths of 745 and $1015 \mathrm{~m}$, are locations of upper and lower slope deposition southwest of the Tregrosse/Lihou/Coringa bank complex (Fig. 1). On the southern margin of the Townsville Trough, Sites 816 and 826 in water depths of about 430 $\mathrm{m}$ penetrated a carbonate build-up on the northwestern corner of the Marion Plateau, whereas Site 815 in slightly deeper water $(465 \mathrm{~m})$ was situated to recover the forereef deposits. The Townsville Trough transect was designed to determine the composition and age of the carbonate build-ups and to evaluate the causes for their demise (Davies, McKenzie, Palmer-Julson, et al., 1991). In addition, the Queensland Plateau sites were intended to study facies distribution in response to change in sea level across a platform-slope transition in a pure carbonate system and provide stratigraphic and age data for interpreting event stratigraphy.

Using the extensive intercalibration of the biostratigraphies from 16 drill sites (Gartner et al., this volume), this chapter attempts to broadly synthesize the results of both the Leg 133 drilling expedition (Davies, McKenzie, Palmer-Julson, et al., 1991) and the numerous specialty studies contained in this volume. It concentrates on the overall Cenozoic history of the northeastern Australian margin, dealing primarily with the evolution of the older Queensland and Marion platforms. A second synthesis chapter (Davies and McKenzie, this volume) focuses on the relatively more recent Pliocene-Pleistocene development of the Great Barrier Reef.

\section{PLATE MOTIONS AND CENOZOIC ENVIRONMENTS}

The initiation and long-term development of the carbonate platforms on the northeastern Australian margin have been uniquely influenced by the northward drift of the Australian Plate throughout the Cenozoic. Hot-spot and magnetostratigraphic studies indicate that the margin was located between $29^{\circ}$ and $44^{\circ} \mathrm{S}$ at the end of the Eocene and moved steadily northward to its present location between $9^{\circ}$ and $24^{\circ} \mathrm{S}$ (summarized in Davies et al., 1989). This latitudinal motion transported the Queensland and Marion plateaus into progressively warmer water masses from temperate to subtropical to tropical zones. 


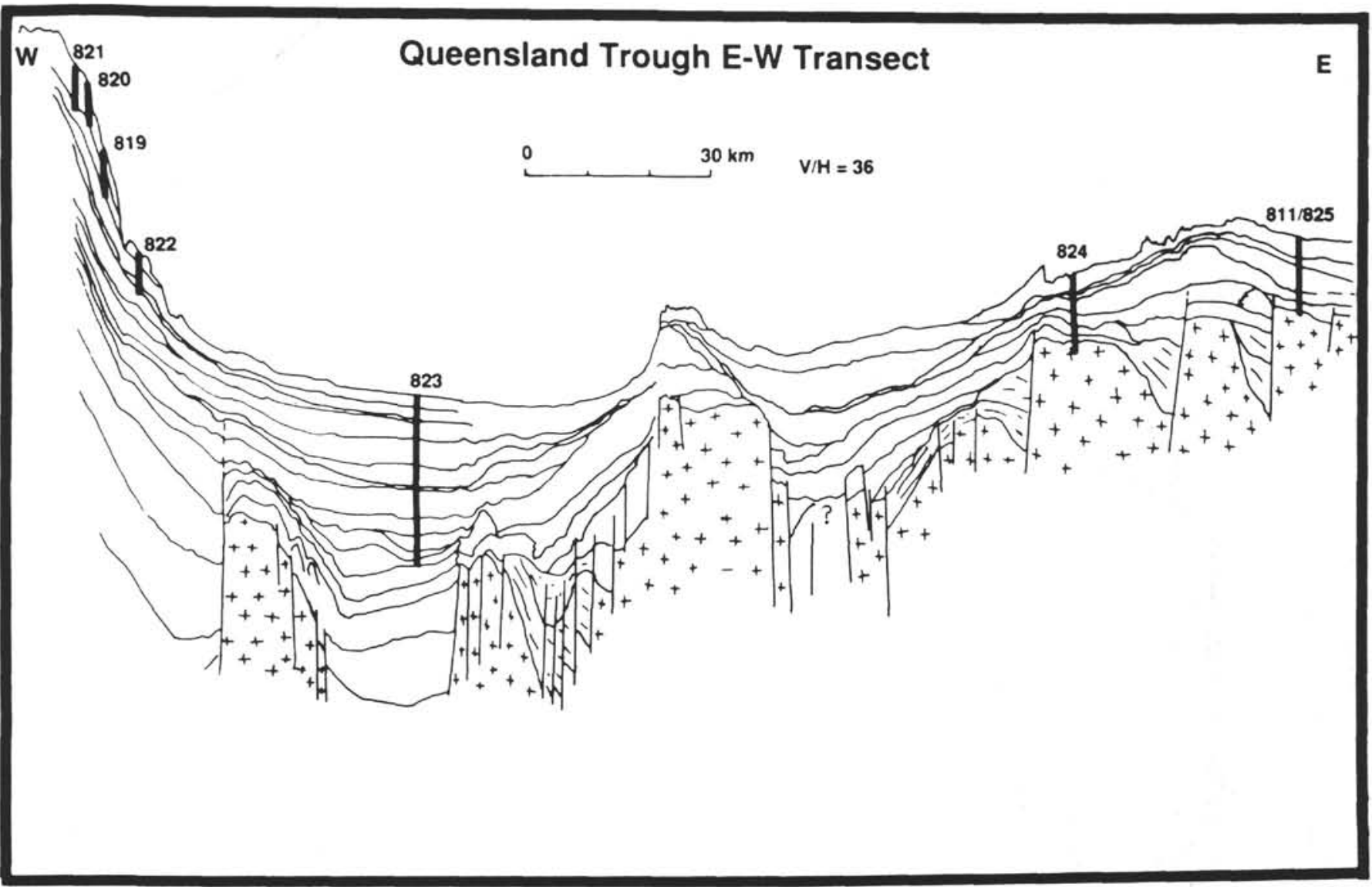

Figure 2. Schematic transect across the Queensland Trough.

Based on the projected plate movement and extrapolated surface sea-water temperatures since the Eocene, Feary et al. (1991) predicted that the sedimentary facies cored on the platforms during Leg 133 should reflect these changing water masses as well as short-term climate and oceanographic changes. Drilling fundamentally confirmed their working hypothesis and indicated that the paleoenvironmental changes were operating in a more complex manner and at a faster rate than predicted from the relative plate motions.

Carbonate sedimentation on the Queensland Plateau began during the middle Eocene, when temperate waters transgressed across the platform depositing bryozoan-rich sediments on the drowned, predominantly metasedimentary basement (Davies, McKenzie, PalmerJulson, et al., 1991; Feary et al., this volume; Betzler et al., this volume; Brachert et al., this volume). The presence of interspersed layers containing larger benthic foraminiferal species points to the periodic incursion of warmer waters, but until the late Oligocene, temperate conditions prevailed. During the early Miocene, an environmental change occurred that resulted in the establishment of a major subtropical to tropical platform. This change was too drastic and too rapid to have resulted simply from the steady northward drift of the Australian Plate. Only a major change in paleocirculation patterns, such as the onset of the tropical convergence off northeast Australia (Edwards, 1975), whereby warm tropical waters replaced the cool temperate waters, could account for the observed abrupt change in the carbonate facies.

Once established on both the Queensland and Marion plateaus, the tropical reef complex continued to expand and flourish throughout the middle Miocene (Fig. 4). Beginning in the latest middle Miocene, a decline in carbonate production occurred, with a stepping back of the reefs from the platform margins. During the late Miocene, tropical carbonate production was greatly diminished and nontropical carbonate sediments covered the Queensland platform. Because the Austra- lian Plate maintained a steady northward course throughout the late Cenozoic, a plate-motion explanation cannot account for this shift from tropical to nontropical facies, because the platforms should have remained within the belt of tropical waters. Once again, factors other than plate motion must have determined the paleoenvironmental conditions. Thus, although the northward movement of the Australian Plate throughout the Cenozoic steered the northeastern margin into warmer waters, facilitating the initiation and long-term development of the carbonate platforms, other factors, such as relative sea level and paleoceanography, combined to control the short-term changes that essentially determined the growth pattern of these dynamic systems.

\section{SEDIMENTARY RESPONSE TO FLUCTUATIONS IN EUSTATIC SEA LEVEL}

Eustatic sea-level control can be a significant factor in the shortterm development of a carbonate platform. In cases where environmental and tectonic conditions remain constant, fluctuations in eustatic sea level can regulate shallow-water carbonate production by varying water depth. Rising sea level over a submerged platform top can promote carbonate productivity by providing new space for upward expansion of the growing reef systems. At a reasonable rate of rise in sea-level, the carbonate factory can remain within the photic zone. On the other hand, falling sea level, in the most extreme case, can lead to emergence of the platform top.

During the early to early middle Miocene, tropical reef complexes flourished on the Queensland and Marion plateaus (Fig. 4). Core material obtained from these sequences, from numerous sites on the plateaus, indicates that carbonate productivity continued nearly unabated throughout this period (Davies, McKenzie, Palmer-Julson, et al., 1991). According to the eustatic sea-level curve of Haq et al. 


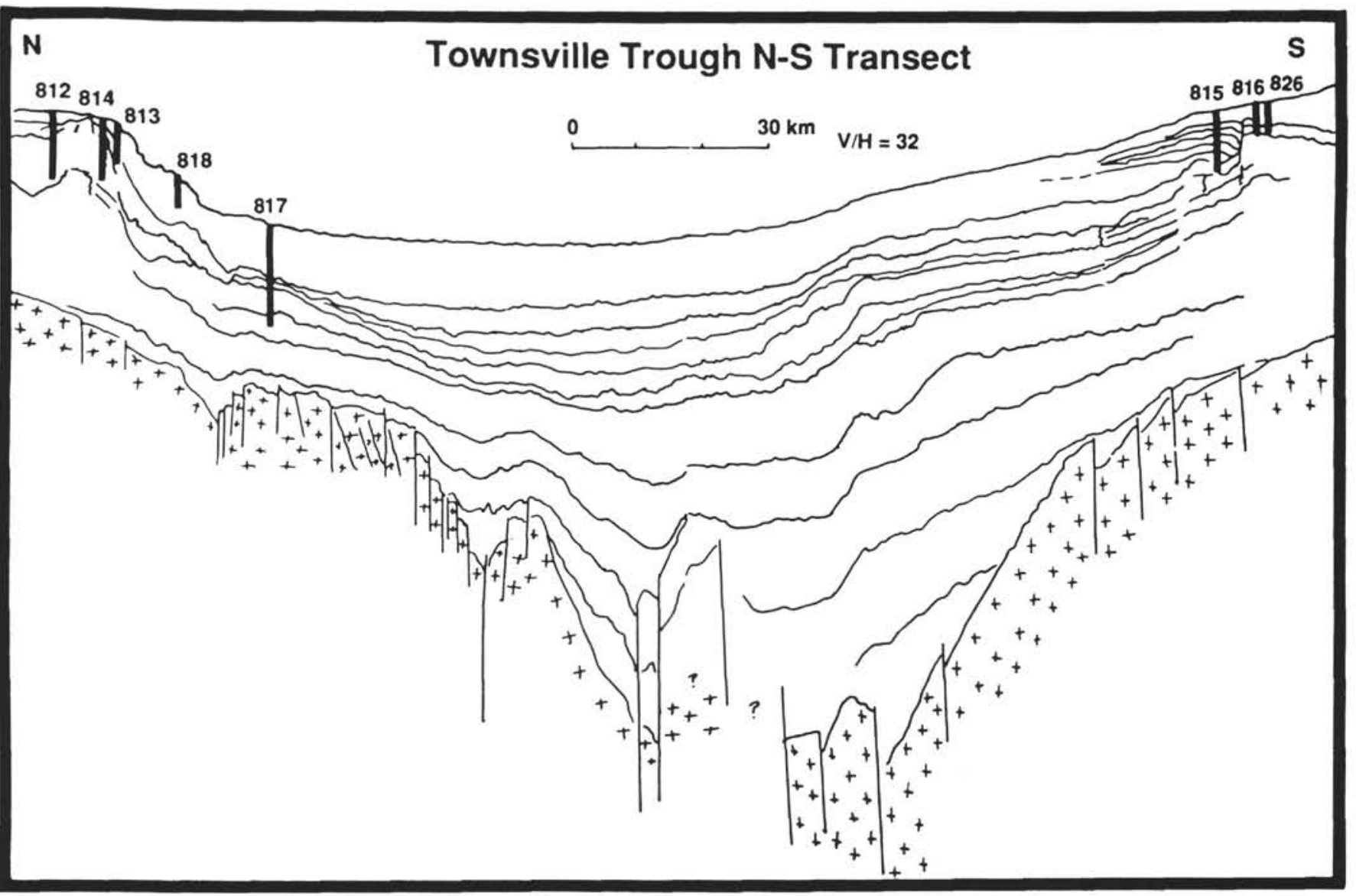

Figure 3. Schematic transect across the Townsville Trough.

(1987; Fig. 4), relatively highstands of sea level predominated during this period with a long-term lowstand centered at about 21 and shortterm lowstands occurring at about 17 and $15 \mathrm{Ma}$. Because recovery was poor in the shallow-water carbonates, it is difficult to state definitively what significance these falls in eustatic sea level may have had on platform productivity. However, the overall tendency toward lower eustatic sea level during the late middle Miocene, which culminated in a major lowstand at $10.4 \mathrm{Ma}$, did profoundly affect the Marion Plateau, leading to a total emergence of the platform top and cessation of shallow-water carbonate productivity (Fig. 4). Because the Queensland Plateau experienced a period of rapid subsidence around $13.7 \mathrm{Ma}$ (see discussion below), the platform top apparently was able to maintain continued production throughout this approximately $4 \mathrm{~m}$.yr. period of an overall lowstand, even though it may have become partially emergent at some locations.

Besides controlling shallow-water carbonate production on platform tops, fluctuations in eustatic sea level can also influence the style of sedimentation on adjoining slopes and in adjacent basins. Slopes can become destabilized with changing sea level, causing mass wasting and subsequent sedimentation of gravity deposits, such as turbidites, slumps, and debris flows. Eustatic lowstands tend to initiate slope failures that produce thick turbidites and debris flow and slump deposits. Watts et al. (this volume) correlated late Neogene/Quaternary fluctuations in eustatic sea level with the types and frequency of gravity deposits distributed throughout the expanded 1011-m sequence at the deep $(1638 \mathrm{~m})$ basinal Site 823 in the Queensland Trough. Variations in the composition of the deposits, which are mixtures of reworked carbonate and siliciclastic material, reflect changes in shallow-water sedimentation patterns on the adjoining Queensland Plateau and northeastern Australia continental shelf. They found that intervals having abundant gravity deposits correlate with eustatic lowstands of sea level.
The Site 823 sequence shows that slope instability and associated gravity deposits, once initiated during a eustatic lowstand, can continue during subsequent sea level rises. Also, they noted that the uppermost Miocene/lower Pliocene hemipelagic mud, which tends to be readily deformed, appears as slumped intervals that coincide with eustatic highstands.

During eustatic lowstands, when carbonate platform tops were exposed, the deposition of both reworked micritic and bioclastic carbonates at deeper sites around the platforms should have been diminished because the area and, hence, amount of shallow-water carbonate production was drastically reduced. Conversely, eustatic highstand flooding of the platforms should have facilitated carbonate production and, as a consequence, enhanced the amount of neritic material available for erosion and off-platform transport. This latter phenomena is termed "high-stand shedding" and is contrary to siliciclastic systems on continental margins that have low amounts of highstand deposition in deeper parts of the basins. In contrast, during low sea levels, siliciclastic material was deposited on the outer margins and subsequently transported into the deeper basins, where sedimentation rates were enhanced ("low-stand shedding") (Droxler and Schlager, 1985; Reymer et al., 1988). Applying the concept of "high-stand shedding" in a pure carbonate system where factors other than eustatic sea level, such as paleoceanography or tectonics, have a greater control on carbonate platform development can be difficult (Droxler et al., this volume). In the case of the slope sites on the Queensland Plateau, correlation of sedimentary responses with late Neogene eustatic sea-level changes were inconclusive in a pure carbonate system where surfacewater temperatures controlled carbonate bank productivity and subsidence pulses determined bank-top water depths (see discussion below).

Nevertheless, the process of highstand biogenic production, with subsequent erosion and transport of shallow-water material from the 


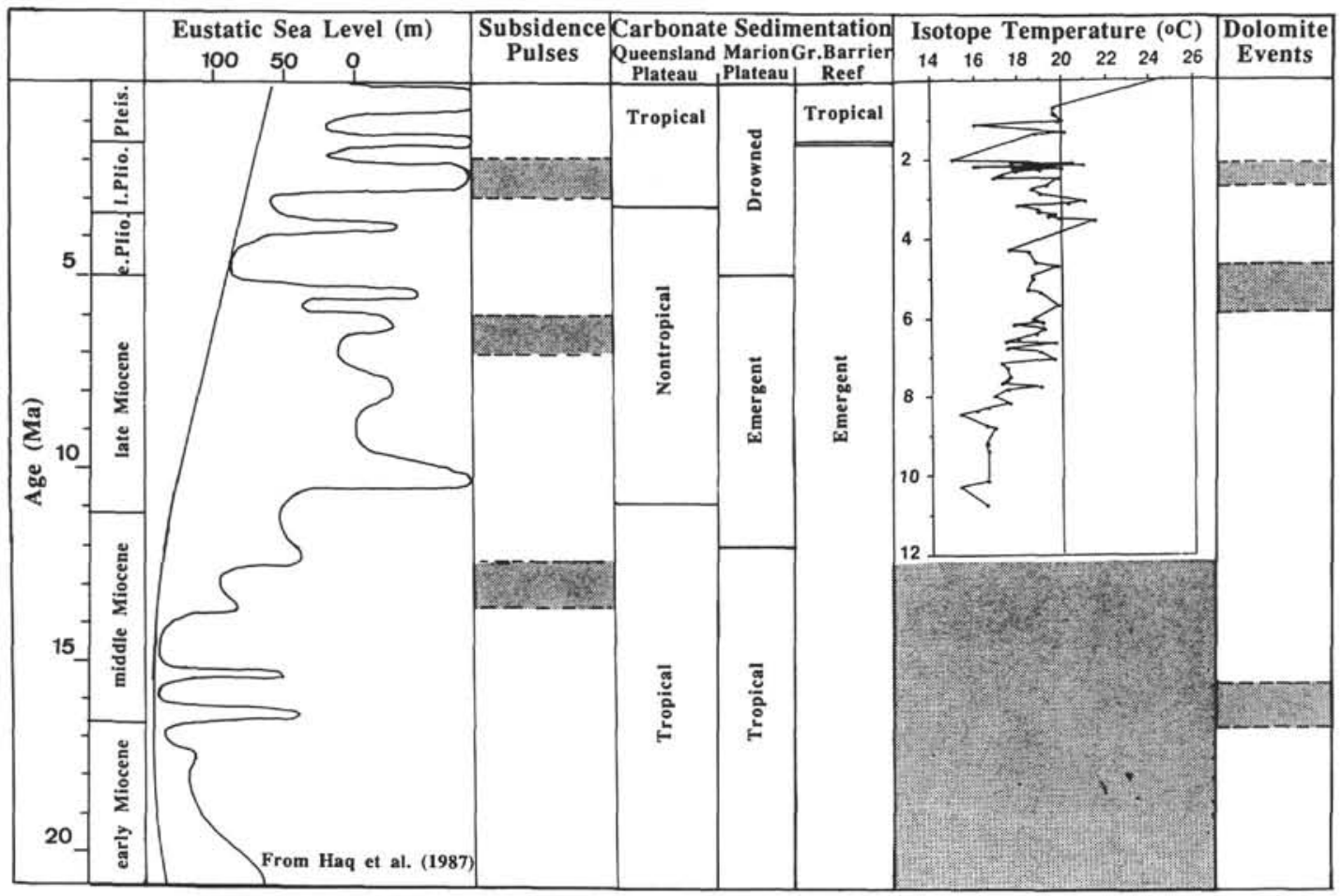

Figure 4. Diagrammatic correlation of Neogene stratigraphic events on the northeastern Australian margin illustrating the interplay of such factors as variations in eustatic sea level, subsidence pulses (Katz and Miller, this volume), paleoceanographic changes as recorded in isotope temperatures (Isern et al., this volume), and periodic dolomitization events (McKenzie et al., this volume) on carbonate platform evolution and post-deposition diagenetic history (see text for discussion).

carbonate platform, can be tentatively documented with specific Leg 133 results. For example, the presence of neritic limestone clasts and bioclastic components that have reefal affinities in lowermost upper Miocene (about 10.2-8.2 Ma) gravity deposits in both slope and basinal sequences, Sites 811 and 823 , respectively, may be related to erosion and off-bank transport of shallow-water carbonates from the bank tops during a highstand (Davies, McKenzie, Palmer-Julson, et al., 1991, Watts et al., this volume). This approximately 2 m.y. period was dominated by a significant eustatic highstand, following the dramatic lowstand at 10.4 Ma (Haq et al., 1987) (Fig. 4).

At Site 817, on the lower slopes of the Queensland Plateau, an erosional unconformity occurs that apparently represents a sequence boundary clearly evident in seismic profiles and is probably related to the major sea level fall that occurred at the middle/late Miocene boundary (10.4 Ma) (Davies, McKenzie, Palmer-Julson, et al., 1991). Interestingly, the sediments infilling the channel contain reworked late middle Miocene age foraminifers, obviously from older sediments exposed and eroded on the upper platform slopes or margins. The infilling occurred during the $2 \mathrm{~m}$.y. highstand period after the dramatic lowstand at $10.4 \mathrm{Ma}$. This deposit, as with the synchronous deposits at Sites 811 and 823 , may likewise be associated with highstand shedding, whereby older sediments exposed on the upper platform slopes or margins are eroded and transport downslope.

\section{SUBSIDENCE PULSES AND RISING SEA LEVEL}

Relative sea level on a continental margin can be regulated by vertical tectonic movements, with uplift producing a falling sea level and subsidence a rising sea level. Late Cretaceous extensional tectonics on the northeastern Australian margin formed a rift basin system that provided large shallow-water areas suitable for carbonate platform growth. But once formed, these blocks did not subside uniformly as a result of post-rift thermal cooling, but in a step-wise fashion, with subsidence pulses occurring during specific time intervals (Davies et al., 1989; Fig. 4). The timing of these pulses proved to be a major factor determining whether a platform could maintain its growth rate in conjunction with other environmental changes. Discrete subsidence pulses on the Queensland Plateau were calibrated at approximately $13.7,7$ to $6 \mathrm{Ma}$, and 3 to $2 \mathrm{Ma}$. The occurrence of these subsidence pulses is associated with changes in depth-dependent benthic foraminiferal assemblages that are interpreted to occur as a result of rapid water-depth increases (Davies, McKenzie, Palmer-Julson, et al., 1991; Katz and Miller, this volume). On the Marion Plateau, only the subsidence pulse at 7 to $6 \mathrm{Ma}$ was apparently significant, whereas the 3 to 2 Ma pulse had important consequences for the Australian margin.

Changes in sedimentation type on the slopes of the Queensland Plateau record the pulse centered around 13.7 Ma. At Site 817, the pulse is reflected by an upward decrease in the neritic carbonate sand content of the sediments, indicating a decreased supply from the shallower waters on the platform with the relative rise in sea level. At Sites $811 / 825$, a rapid change from tropical neritic deposits, possibly in a forereef or backreef environment, to deeper water deposits, periplatform ooze with gravity- and debris-flow deposits, marks the subsidence pulse (Davies, McKenzie, Palmer-Julson, et al., 1991). As a consequence of this accelerated subsidence event, the Queensland Plateau remained submerged during the late middle Miocene, facilitating continued production of carbonate bank sediments. In contrast, on the Marion Plateau, relative sea level was falling at this time, which led to the emergence of the late early to middle Miocene tropical reef complex and the cessation of carbonate bank production. As mentioned above, this exposure was undoubtedly a result of the overall global sea level fall that occurred in the late middle Miocene (Haq et al., 1987) and indicates that the 13.7-Ma subsidence pulse was ineffective or nonexistent on the western side of the Townsville Trough.

A second subsidence pulse occurred within the late Miocene, between 7 and $6 \mathrm{Ma}$, a period associated with cooler water sedimentation on the northeastern Australian margin (Davies, McKenzie, Palmer-Julson, et al., 1991; Isern et al., this volume; Fig. 4). Carbonate 
bank production had diminished significantly beginning in the late Miocene as a result of paleoceanographic changes (see discussion below), and tropical reefs were evidently nonexistent on the Queensland Plateau (Betzler et al., this volume). Eustatic sea level rose and then fell between 7 and $6 \mathrm{Ma}$ (Haq et al., 1987). Thus, the accelerated subsidence during this period probably provided accommodation space for nontropical bryozoan/mollusk buildups on the platform margins, as revealed in cores at Site 812 (Davies, McKenzie, Palmer-Julson, et al., 1991). In addition, this subsidence may have facilitated the drowning of the older emergent reefs on the Marion Plateau. Based on the occurrence of late Miocene age (N17) hemipelagic ooze in the residual porosity of upper lower to middle Miocene reefal samples dredged from the Marion Plateau, Pigram et al. (this volume) confirm that the previously emergent reefs were reflooded by seawater at the earliest by $7 \mathrm{Ma}$. Also, dolomitization of middle Miocene reefs at Site 816 occurred during latest Miocene time (McKenzie et al., this volume; Fig. 4), indicating that they were in contact with seawater, the dolomitizing fluid, and thus must have been submerged. However, because of unfavorable environmental conditions, renewed reef growth at Sites 816 and 826 was apparently impossible. On the slopes of the Marion Plateau (Site 815), hemipelagic sedimentation began again at approximately 6.74 Ma after a 4 m.y. hiatus (Gartner et al., this volume). This renewed sedimentation is approximately synchronous with rapid deepening at the site from outer neritic (200-300 m) to upper bathyal (200$600 \mathrm{~m}$ ) paleodepths (Katz and Miller, this volume). Apparently, Site 815 was rapidly lowered into water depths where erosion processes were no longer operative and where hemipelagic sediments began to accumulate.

The most recent subsidence pulse occurred between 3 and $2 \mathrm{Ma}$ on the northeastern Australian margin, a period of overall eustatic sea level fall (Wornardt and Vail, 1991). Although the oxygen-isotope temperatures indicate that a discernible warming of the surface waters took place with renewed carbonate bank production on the Queensland Plateau from about 3.5 Ma (Isern et al., this volume; Fig. 4), the re-establishment of widespread tropical reef growth on the platform approaching that of the late early to middle Miocene did not occur. The rate of subsidence more than compensated for the general global sea level fall of the period and most of the Queensland Plateau sank into upper bathyal (200-600 m) or deeper water depths (Katz and Miller, this volume). The platform was essentially drowned, except for a few isolated areas, where tropical reefs continued to grow, such as Holmes and Tregrosse reefs (Fig. 1). On the slopes at Sites 811/825, 817 , and 818 , this drowning has been manifested by a temporary but significant increase in the depositional rate of fine-grained bankderived carbonate (Droxler et al., this volume). At the margin sites (Sites 812 and 814), periplatform ooze deposition commenced over hardground surfaces that represented condensed sedimentation for the previous several million years (Davies, McKenzie, Palmer-Julson, et al., 1991; Glenn et al., this volume). With this most recent subsidence pulse, the Queensland Plateau sank into water depths that lowered most of its upper surface deep below the photic zone $(>100$ $\mathrm{m}$ ) and essentially eliminated the possibility for rejuvenation of the once extensive tropical reefs on the platform.

In contrast, the subsidence pulse between 3 and 2 Ma submerged the Australian shelf, bringing this surface into neritic water depths. The sudden appearance of neritic bioclasts with increased detrital quartz in the gravity deposits at Site 823 at $2.6 \mathrm{Ma}$ reflects this transformation (Davies, McKenzie, Palmer-Julson, et al., 1991; Watts et al., this volume). From 2.6 Ma, the location for a new tropical reef system on the Australian shelf, the Great Barrier Reef, was prepared and awaited only changes in paleoceanographic conditions that would facilitate its initiation as discussed below.

\section{INFLUENCE OF PALEOCEANOGRAPHY ON PLATFORM PRODUCTION}

Carbonate platforms are dynamic systems because they have the ability to produce their own sediment. In general, the growth pattern and development of a platform is dependent on shallow-water carbonate production, which in turn requires favorable temperature and salinity conditions and clear waters to flourish. The widespread occurrence of tropical reef complexes on the Queensland and Marion plateaus during the early to middle Miocene is itself documentation that optimum conditions for shallow-water carbonate production must have existed during this approximately 10 m.y. interval (Davies, McKenzie, Palmer-Julson, et al., 1991) (Fig. 4). At the middle to late Miocene boundary, a major fall in eustatic sea level led to the emergence of the Marion Plateau and, hence, the demise of the tropical reef complexes. However, reef growth also declined on the Queensland Plateau, which apparently remained predominantly submerged during the late Miocene.

The almost complete disappearance of the tropical fauna and flora on the isolated Queensland Plateau and the replacement by nontropical bio-assemblages cannot simply be ascribed to relative changes in sea level. Environmental changes must have taken place to cause such a radical biological change, as well as a dramatic decrease in production of shallow-water carbonate sediment. Off-bank transport of carbonate material to the adjacent margins was reduced to such an extent that pelagic sedimentation dominated on the slopes (Davies, McKenzie, Palmer-Julson, et al., 1991). Leg 133 post-cruise results indicate that the observed transformation from tropical to nontropical production and back again must be related to major changes in the regional paleoceanography.

In particular, the oxygen-isotope temperature record produced from the analysis of planktonic foraminifers demonstrates that cooler surface waters were prevalent on the northeastern Australian margin during the late Miocene (Isern et al., this volume; Fig. 4). Average surface-water temperatures during most of the late Miocene were probably below $20^{\circ} \mathrm{C}$, temperatures well below the tolerance limit of a healthy tropical reef. Decreased surface-water temperatures may have resulted from a reorganization of ocean circulation in the Coral Sea region that weakened the dominant warm surface waters of the South Equatorial Current and permitted cooler subtropical lower water to surface (Isern et al., this volume). An apparent warming of the surface waters occurred during the late Pliocene, allowing for renewed carbonate bank production, as evidenced by a renewed flux of periplatform ooze onto the slopes of the Queensland Plateau (Davies, McKenzie, Palmer-Julson, et al., 1991; Haddad et al., this volume). However, during the same period, a subsidence pulse brought much of the formerly productive shallow-water areas into deeper waters, essentially drowning most of the Queensland Plateau. Thus, with the return to warmer surface waters in the late Pliocene, and particularly during the Pleistocene, growth sites for the rejuvenation of tropical reef complexes were severely restricted to isolated buildups where reef complexes exist today (Fig. 1).

At the same time, the rapid subsidence of the Australian continental shelf combined with renewed favorable paleoceanographic conditions allowed the locus of tropical carbonate production on the northeastern Australian margin to shift from the Queensland Plateau to a new location on the continental margin, the site of the modern Great Barrier Reef. Nevertheless, the isolated tropical reefs on the Queensland Plateau played a significant role, serving as sheltered nurseries where species could retreat during Pleistocene glacial emergences of the Great Barrier Reef, only to be rapidly reseeded during interglacial transgressions (Davis and McKenzie, this volume).

As mentioned above, the middle to late Miocene emergence of the Marion Plateau led to the demise of the tropical reef complexes that had covered wide expanses of the platform. As sea level rose during the late Miocene, cool surface waters probably inhibited the re-establishment of reef growth. Yet, reef growth did not reinitiate when surface waters warmed during the late Pliocene/Pleistocene, except in a few isolated locations, where they exist today (Fig. 1). Because of its geographic position, the Marion Plateau became a site of siliciclastic deposition in the Pliocene, when an apparent change in the paleocirculation pattern resulted in the transport of terrestrial muds along the 
margin. Deposition of a massive contourite occurred where the sediment-laden current impinged on the slopes (Davies, McKenzie, Palmer-Julson, et al., 1991). A continued influx of fine-grained hemipelagic sediment feed to the development of a huge contourite on the slopes that eventually encroached on the formerly emergent, now drowned, shallow-water carbonate complex essentially covering the platform with mud. Undoubtedly, in the case of the Marion Plateau, water clarity contributed significantly to the ultimate late Neogene demise of the reef complex.

\section{MECHANISM AND TIMING OF DOLOMITIZATION}

Massive dolomitization of large carbonate platforms has occurred extensively in the geologic past, but this process has not been directly observed in modern systems. Thus, the fundamental mechanism promoting massive dolomitization of carbonate platforms is poorly understood. Seawater is generally considered to be the best and most likely dolomitizing solution, but the hydrologic force pumping water through the carbonate sediments remains unclear. Several hydrologic models have been formulated, but they cannot be thoroughly tested or unconditionally proven because of the lack of direct observations of the dolomitization process. This dilemma has produced a longstanding problem in modern geology, often called the Dolomite Problem (e.g., Machel and Mountjoy, 1986; McKenzie, 1991). Preliminary drilling results from Leg 133 provide new information on platform dolomitization regarding the driving mechanism and the timing of dolomitization events.

On the Queensland Plateau, strontium isotope ages indicate that dolomitization of shallow-water carbonates occurred during at least three periods and may possibly be an ongoing process (Fig. 4). At Site 817 on the slopes of the Plateau, latest early Miocene(?) carbonates show pervasive dolomitization with a sucrosic texture (Davies, McKenzie, Palmer-Julson, et al., 1991). Surprisingly, strontium isotope dating of two deeply buried dolomite samples indicates a stratigraphic age inversion, that is, younger dolomite (5.2 Ma) underlies an older dolomite (16.2 Ma) (McKenzie et al., this volume). At Site 812 , strontium isotope ages of dolomitized middle Miocene, shallowwater, tropical reef-related carbonates indicate multiple dolomitization periods; a stratigraphically lower event at $5.2 \mathrm{Ma}$ and an overlying younger event between 1.8 and $2.4 \mathrm{Ma}$. Again, surprisingly, the younger dolomite is stratigraphically overlain by an older dolomite having a strontium isotope age of 5.0 Ma (McKenzie et al., this volume). These preliminary results strongly imply that dolomitization of middle to late Miocene carbonates on the Queensland Plateau has occurred during specific time intervals. Perhaps, it is only a coincidence that, within the error limits of the strontium isotope age determination method, there appears to be a close correlation between periods of subsidence pulses and dolomitization events (Fig. 4).

Dolomitization may be an ongoing process, whereby the strontium isotope ratios for the youngest dolomitization event (1.8 to $2.4 \mathrm{Ma}$ ) could represent maximum ages. This ongoing activity would be consistent with the geochemistry and strontium isotope ages of pore waters squeezed from the unconsolidated sediments cored on the Queensland Plateau (Davies, McKenzie, Palmer-Julson, et al., 1991; Elderfield et al., this volume; Swart et al., this volume). The porewater geochemistry indicates that modern seawater is currently being drawn into and circulated through the platform sediments, with an undetermined amount of dolomitization occurring along its path (Swart et al., this volume).

At Site 816 on the Marion Plateau, pervasive dolomitization of the middle Miocene reef complex occurred between 8.8 and $5.2 \mathrm{Ma}$, based on strontium isotope dating (Davies, McKenzie, Palmer-Julson, et al., 1991; Pigram et al., this volume; McKenzie et al., this volume). Within the error of the method, the ages tend to become younger upsection. Oxygen and carbon isotope compositions of the dolomite indicate that seawater was the dolomitizing fluid (McKenzie et al., this volume). Timing of the dolomitization appears to coincide with a period of increased eustatic sea level and as well as slightly post-date a rapid subsidence pulse (Haq et al., 1987; Fig. 4), both of which resulted in the resubmergence of the Marion Plateau. Perhaps, the rising sea level was the driving force flushing seawater through the shallowwater carbonates and leading to their pervasive dolomitization.

Thermal convection models for dolomitization of carbonate platforms have been previously postulated (Kohout et al., 1977; Fanning et al., 1981; Simms, 1984). A geothermal gradient induced by a higher heat flow beneath the carbonate platform could provide the hydrologic force driving the postulated circulation. A strong horizontal density gradient could be established between the water heated within the platform interior and the cooler seawater surrounding the platform. The density difference would lead to the establishment of a convection half-cell as cooler waters enter the platform to replace the upward-flowing warmer platform waters. Preliminary temperature measurements made during the logging of some holes on the Queensland Plateau (Davies, McKenzie, Palmer-Julson, et al., 1991) indicate the occurrence of anomalously high temperatures at depth that could be consistent with the thermally driven circulation model for the massive dolomitization of an isolated carbonate platforms. Undoubtedly, the fluid circulation and heat flow within the Queensland Plateau warrant further evaluation, and future investigations may provide an actualistic test of this fundamentally important dolomitization model.

\section{SUMMARY AND CONCLUSIONS}

Drilling of carbonate platforms on the northeastern Australian margin demonstrated that a complex interplay of various factors, such as variations in eustatic sea level, subsidence pulses, and paleoceanographic changes, combined to control their Cenozoic evolution. In most cases, not a single factor, but a combination of factors was in operation at any specific time.

Obviously, subsidence pulses are important as they can move a platform top from a subaerially exposed environment into a shallow neritic setting, providing suitable conditions to promote the initiation of nontropical or tropical carbonate production. This was the case during the onset of temperate-water carbonate sedimentation on the middle Eocene Queensland Plateau or the Pleistocene initiation of the Great Barrier Reef. In addition, periods of accelerated subsidence can play a critical role in the evolution of carbonate platforms by causing them to remain submerged regardless of synchronous rises and falls in eustatic sea level. The effect of this control was particularly important on the Queensland Plateau during the late middle to late Miocene. A rapid subsidence pulse kept the platform top submerged when the nearby Marion Plateau was experiencing emergence due to long-term eustatic lowering of sea level. The shallow-water carbonate factory on the Queensland Plateau continued to operate throughout this period and apparently only shut down in the late Miocene as a result of unfavorable changes in surface-water conditions.

Aside from the relative sea level control, Leg 133 drilling results documented that paleoceanography can play an essential part in both isolated and attached carbonate platform development. Major changes in paleocirculation on the northeastern Australian margin apparently controlled platform productivity during two distinct periods. In the early Miocene, a sudden warming of surface waters led to the development of widespread reef complexes on the Queensland and Marion plateaus, which flourished throughout most of the middle Miocene. Warm tropical conditions waned as a significant cooling of surface waters occurred during the late Miocene. This led to the replacement of the flourishing reefs on the Queensland Plateau by nontropical bio-assemblages with drastically decreased productivity.

The Marion Plateau was emergent during the earliest late Miocene as a result of a major fall eustatic sea level that was centered at 10.4 $\mathrm{Ma}$. With tectonic submergence and rising sea level during the latest late Miocene, neither tropical nor nontropical carbonate sedimentation could be re-established on the platform, probably as a consequence of changes in regional paleocirculation patterns. The appearance of a 
longshore sediment-laden current impinging on the platform margin led to the piling up of thick deposits of hemipelagic muds on the slopes, eventually covering the platform top. These deposits essentially choked out almost any possibility for the renewal of extensive shallow-water carbonate production, except for isolated locations.

The ultimate demise of extensive reefal complexes on the Queensland Plateau had a different cause from those on the Marion Plateau. Rapid subsidence pulses during or following the late Miocene period of unfavorable climatic conditions eventually led to the drowning of most of the platform, as the once productive areas could not keep up with the rising sea level. The modern Queensland Plateau is currently a drowning platform that is holding onto a few isolated remnants of tropical carbonate production. A future subsidence pulse may cause the final drowning of this platform. This may have important consequences for the Great Barrier Reef, as the isolated reefs on Queensland Plateau, which are thought to serve as biological havens for the organisms needed to repopulate the Australian shelf after each Quaternary glacial emergence, could be eliminated.

In summary, the factors controlling carbonate platform initiation, growth, and demise are multiple and often interactive. The unlimited possibility of combining these factors in time and space determines the unique developmental history of an individual platform. Ocean drilling on the northeastern Australian margin has substantiated the complicated nature of carbonate platform evolution but, in doing so, has provided us with new models and new approaches for the study of other modern or ancient carbonate systems.

\section{ACKNOWLEDGMENTS}

We would like to acknowledge gratefully the scientific contributions of all our shipboard and shore-based colleagues to the content of this study, although we accept full responsibility for the interpretations stated here. Without the hard work and cooperative spirit of this scientific party during Leg 133 and during our post-cruise efforts, so much data could not have been produced in so little time. In addition, we would like to thank the ODP marine technical team, the SEDCO drilling crew, and the JOIDES Resolution marine operations staff for making Leg 133 an operational success. Valuable comments by A. Isern on an earlier draft of the manuscript and reviews by R.T. Buffler and J. Kennard greatly improved it. JAM acknowledges Swiss Nationalfond Research Grant No. 20-29'052.90 for partial support of this work.

\section{REFERENCES}

Davies, P.J., McKenzie, J.A., Palmer-Julson, A., et al., 1991. Proc. ODP, Init. Repts., 133: College Station, TX (Ocean Drilling Program).

Davies, P.J., Symonds, P.A., Feary, D.A., and Pigram, C.J., 1989. The evolution of the carbonate platforms of northeast Australia. In Crevello, P.D.,
Wilson, J.L., Sarg, J.F., Read, J.F. (Eds.), Controls on Carbonate Platform and Basin Development. Spec. Publ.-Soc. Econ. Paleontol. Mineral., 44:233-258.

Droxler, A.W., and Schlager, W., 1985. Glacial versus interglacial sedimentation rates and turbidite frequency in the Bahamas. Geology, 13:799-802.

Eberli, G.P., 1991. Growth and demise of isolated carbonate platforms: Bahamian controversies. In Müller, D., McKenzie, J., and Weissert, H. (Eds.), Controversies in Modern Geology: Evolution of Geological Theories in Sedimentology, Earth History and Tectonics: London (Academic Press), 231-248.

Edwards, A.R., 1975. Southwest Pacific Cenozoic paleogeography and an integrated Neogene paleocirculation model. In Andrews, J.E., Packham, G., et al., Init. Repts. DSDP, 30: Washington (U.S. Govt. Printing Office), $667-684$.

Fanning, K.A., Byrne, R.H., Breland, J.A., Betzer, P.R., Moore, W.S., and Elsinger, R.J., 1981. Geothermal springs of the West Florida Continental Shelf: evidence for dolomitization and radionuclide enrichment. Earth Planet. Sci. Lett., 52:345-354.

Feary, D.A., Davies, P.J., Pigram, C.J., and Symonds, P.A., 1991. Climatic evolution and control on carbonate deposition in Northeast Australia. Palaeogeogr., Palaeoclimatol., Palaeoecol., 89:341-361.

Haq, B.U., Hardenbol, J., and Vail, P.R., 1987. Chronology of fluctuating sea levels since the Triassic. Science, 235:1156-1167.

Kohout, F.A., Henry, H.R., and Banks, J.E., 1977. Hydrogeology related to geothermal conditions of the Floridian Plateau. In Smith, K.L., and Griffen, G.M. (Eds.), The Geothermal Nature of the Floridian Plateau. Spec. Publ.-Fl. Dep. Nat. Resour. Bur. Geol., 21.

Machel, H.-G., and Mountjoy, E.W., 1986. Chemistry and environments of dolomitization-a reappraisal. Earth-Sci. Rev., 23:175-222.

McKenzie, J.A., 1991. The dolomite problem: an outstanding controversy. In Müller, D.W., McKenzie, J.A., and Weissert, H. (Eds.), Controversies in Modern Geology: Evolution of Geological Theories in Sedimentology, Earth History, and Tectonics: London (Academic Press), 35-54.

Reymer, J.J.G., Schlager, W., and Droxler, A.W., 1988. Site 632: PliocenePleistocene sedimentation cycles in a Bahamian basin. In Austin, J.A., Jr., Schlager, W., et al., Proc. ODP, Sci. Results, 101: College Station, TX (Ocean Drilling Program), 213-220.

Simms, M., 1984. Dolomitization by groundwater-flow systems in carbonate platforms. Trans. Gulf Coast Assoc. Geol. Soc., 34:411-420.

Wornardt, W.W., and Vail, P.R., 1991. Revision of the Plio-Pleistocene cycles and their application to sequence stratigraphy and shelf and slope sediments in the Gulf of Mexico. Trans. Gulf Coast Assoc. Geol. Soc., 41:719-744.

\footnotetext{
- Abbreviations for names of organizations and publication titles in ODP reference lists follow the style given in Chemical Abstracts Service Source Index (published by American Chemical Society).
}

Date of initial receipt: 2 October 1992

Date of acceptance: 5 April 1993

Ms 133SR-287 